\title{
Comparison of Depression Severity and Sexual Satisfaction Between Fertile and Infertile Women in Iran: A Population Based Case-Control Study
}

\author{
Katayoun Bakhtiar \\ Lorestan University of Medical Sciences \\ Arash Ardalan \\ Westlake High School \\ Farzad Ebrahimzadeh \\ Lorestan University of Medical Sciences \\ Fatemeh Bastami ( $\square$ fatemeh2011bastami@gmail.com ) \\ Lorestan University of Medical Sciences https://orcid.org/0000-0003-1502-2774 \\ Mohammad Almasian \\ Lorestan University of Medical Sciences
}

\section{Research}

Keywords: Depression, Sexual Satisfaction, Infertility, Case-Control study, Iran

Posted Date: May 21st, 2020

DOI: https://doi.org/10.21203/rs.3.rs-30104/v1

License: (1) (1) This work is licensed under a Creative Commons Attribution 4.0 International License. Read Full License 


\section{Abstract}

Background: Depression and sexual dissatisfaction are among the most common psychological factors caused by infertility. Infertility is an important topic in Iranian culture and many studies have already targeted them. The aim of this study was to compare the severity of both depression and sexual dissatisfaction between fertile and infertile groups of women in Iran.

Methods: A number of 180 infertile and 540 fertile women participated in this case-control study. The cases were selected through a combination of multistage stratified and cluster sampling method. For each infertile woman, three fertile women were randomly selected. Data gathering instrument consisted of demographic variables, Depression Inventory Scale, Second Edition, and the Linda Berg Sexual Satisfaction Questionnaire. The multivariate marginal model and SPSS 21 software were used for data analyses with a significance level of 0.05 .

Results: After adjusting for the effect of confounding variables, the marginal model showed the odds of depression increased by approximately 21.305 times among cases compared to control subjects (OR $=21.305,95 \% \mathrm{Cl}$ for OR:14.75-32.021, $\mathrm{P}<0.001)$. This model also found that by moderating the effect of confounding variables, infertility increased the odds of low sexual satisfaction by approximately 15.560 times $(\mathrm{OR}=15.560,95 \% \mathrm{Cl}$ for $\mathrm{OR}=5.089-47.571, \mathrm{p}<0.001)$. Chi-square test (Monte Carlo Simulation) showed a significant relationship between infertility treatment and severity of depression in infertile group of women $(P=0.001)$. Severe cases of depression were mostly seen among women who received IVF treatment.

Conclusion: The overall severity of depression and sexual dissatisfaction were higher in infertile group than that of fertile one. Also, most cases of severe depression were seen in IVF clinics, which may boost their depression. The results of this study may help reveal the psychological and social aspects of infertility in, Iran.

\section{Background}

Infertility is defined as inability to conceive after a year of regular, unprotected intercourse. That is categorized to primary and secondary infertility. In primary infertility, there is no history of a complete pregnancy, while in secondary infirtility there has been at least one pregnancy developed delivering a newborne(1). Infirtility is estimated to affect $8-12 \%$ of couples of reproductive age group worldwide (2). According to World Health Organization 10-15\% of women are infertile around the world(3). A study reported $17.3 \%$ of Iranian women are currently suffering from infertility. Male partner are rercognized as the primary cause in $29.1 \%$ of cases, while ovarian defects contributed to $39.7 \%$ of main reasons (4).

Infertility can be a frustrating emotional experience. It may cause a number of psychological issues such as tension, anxiety, depression, low levels of self-esteem, and sexual dissatisfaction(5). The resulted psychosocial issues adversly affect female gender more than her spouse (6), especially in societies where childbearing is considered as a fundamental task of women (4, 7, 8). Therefore an infertile woman may present with high level of irritation which affect her relationship with others including her spouse. Likewise, infertile women are more likely to develop mental illnesses, marital dissatisfaction, and impaired quality of life compared to the individuals of fertile group (9). While male facors account for $20-30 \%$ of infertility cases, in reality, they contribute to more than $50 \%$ of cases in the end (2).

Although infertility is considered as a catostrophic phenomen for couples worldwide, studies show that the adverse psychological effects of infertility are found to be greater among women than that of men (2).This is because motherhood has traditionally been accepted as an essential role for women in Iranian culture. Many times, an infertile woman believes she cannot imagine a childless life while his spouse may express a different feeling $(10,11)$. In general, infertile women are more likely than men to seek for treatment for which the female gender or the couple go through emotional and financial hardship(12). Studies have reported a great deal of complications such as fatigue, depression, stress, and lack of self-esteem as psychological consequences of infertility among infertile women $(11,13,14)$.

Sexual satisfaction is also unfavorably affected by infertility due to decreased self-esteem, depression, and anxiety(14). This may let the couple fail to conceive as well and create a defective cycle in which sexual dissatisfaction and infertility may cause each other. A depressed woman may feel hopeless, helpless, worthless, or guilty. She may even lose her desire to encounter in sexual activity $(15,16)$. According to a study, $50-60 \%$ of couples reported a significant reduction in sexual satisfaction during the course 
of infertility treatment(3). Decreased sexual dissatisfaction has other underlying causes such as a history of trauma, rape, mental illnesses and divorce (17-19).

Both mental health and sexual satisfaction are psychological factors that may be adversely affected by infertility and the process of treatment. Lack of attention to emotional disorders of an infertile couple as well as consequences of infertility such as unfavorable interpersonal relationship, marital dissatisfaction, and decreased sexual desire have created a defective cycle that reduces the success of treatment $(20,21)$. Due to social and cultural value of fertility in Iran, study of infertility is very imperative $(4,8,11)$. Previous studies in Iran have not been conclusive a population based case-control study model(22, 23). The present study is designed based on a scientific model. Through random cluster sampling, five cities in Lorestan province that are politically, socio-economically and geographically scattered were studied. The process of matching was done individually. For one case, three controls were matched which makes the case and control groups as similar as possible except the variable of study. In addition, we controlled the effect of confounders using accurate statistical model in contrast of previous studies. The purpose of this study was to compare the severity of depression and sexual dissatisfaction among fertile and infertile groups of women in Iran.

\section{Methods}

\section{Study design}

This was a case-control study.

\section{Study Population and Sampling Methods}

Participants in this study were selected from the residents of Lorestan province using a combination of multi-stage and cluster sampling methods. A total of nine clusters were identified. Each cluster represented a Lorestan province's countiy. Of these clusters, five clusters were randomly selected based on probability sampling, so the greater the population of a city, the more likely it was to be selected. There were two classifications for infertile women in each city. The first category consisted of women in a gynecological hospital or infertility clinic who were selected by non-probable sequential sampling. This means that information on infertile women was collected sequentially until the number of cases and required information were completed. The second category consisted of women who referred to a gynecologist. In each geographic area, two to four offices were selected using systematic random sampling. In each woman's office, non-probable sequential sampling was used to select the participants.

Infertility was defined as the inability to conceive after a year of regular, unprotected intercourse.

Inclusion criteria for the control group included not suffering from infertility, not being pregnant during the study and at least four months interval between the last delivery and the time the study started from. Also, having Persian literacy skills was one of the entry criteria for both case and control groups. Likewise, there were exclusion criteria such as history of drug abuse, mental or physical disorders, death of loved ones over the previous two years, and lack of enthusiasm for co-operation in studying.

It was estimated that 120 infertile women were appropriate for the case group. However, due to the impact of research design, we had to eventually select 180 people for the case group. Each case subject matched three participants in the control group. A number of 540 women were selected for the control group, resulting in a sample size of 720 .

\section{Questionnaire}

The questionnaire includes three parts. The first part of the questionnaire includes demographic information and background information of the participants such as age, employment status, education of the couple, duration of marriage, personal home, family marriage, history of illnesses, household income, exposure to poison, type of infertility, and cost of infertility treatment.

The second part of the questionnaire mainly includes the Beck Depression Inventory scale. Depression Inventory, Second Edition consists of 21 standardized Questions. This questionnaire is not a diagnostic tool but a screening tool that shows the symptoms of depression in a range of mild to severe. Each one has 4 choices where a score of 0 and 3 indicates a normal and severe state 
of disorder, respectively. A score of 0-9 is considered normal, whereas a score of 10-16 indicates signs mild depression. Likewise, a score of $17-29$ is pointed to signs moderate and a score of 30-63 showes signs severe depression. So that the Scores can flactuate from 0 to 63 . This questionnaire has a correlation coefficient of 0.71 (24). According to the psychometric properties of this questionnaire in Iran, the correlation coefficient between two halves was 0.89 , while retest coefficient of one week interval was 0.94(25). Internal consistency (Cronbach's alpha) was used to assess the reliability of this questionnaire. Cronbach's alpha on a 30-sample sample was 0.91 .

The third part was a sexual satisfaction questionnaire. The questionnaire was developed by Linda Berg in 1997. The validity and reliability of this tool has been localized in previous research in Iran $(22,23)$.Sexual satisfaction in this study is a score that the research unit earns after answering the sexual satisfaction scale. It consists of 25 questions and is rated as always, often, sometimes, rarely and never. (5 points), Never answer (1 point) and if the answers are often, sometimes infrequently (4-3-2, respectively) a score. The score ranges from 17 to 85 . Poor sexuality scored from 11 to 17 , the score of moderate sexual satisfaction ranged from 67 to 52; and good sexual satisfaction ranged a score of 68 to 85 .

\section{STATISTICAL ANALYSIS}

Frequency, mean and standard deviation tables were used to describe the variables. Since the individual-to-individual matching method was used and the data were of a quadratic matching type, both for univariable and multivariable data modeling, the marginal model and specifically the generalized estimation equation (GEE) method in parameter estimation was applied. Basically, GEE was utilized to estimate the parameters of a generalized linear model with an uncertain correlation between outcomes(26).

At first, demographic and contextual variables were compared between fertile and infertile women groups by marginal GEE model. In these GEE method; the logit link function with the exchangable covariance matrix structure was used. In each separate GEE, "infertility status" was considered as the dependent variable, and a single demographic predictor variable was identified as the independent variable. Another marginal GEE model was used to determine the relationship between depression severity and level of sexual satisfaction with demographic variables. In these GEEs, a cumulative logit regression function was employed, and in each separate GEE, severity of depression as well as the level of sexual satisfaction were considered as the dependent variable, while demographic variable included the only predictors.

The influence of confounding factors in the study was controlled. Since the aim of this study was to investigate the effect of infertility on the severity of depression as well as the level of sexual satisfaction in women, variables with a $P$ values less than 0.25 were selected in the univariable approach mentioned above and were included in the multivariable modeling(27-29).

Demographic and contextual variables that were significantly or nearly related to both infertility and the severity of depression or sexual satisfaction were considered as confounding variables.

For multivariate modeling, the cumulative logit link function with exchangeable structure was used for correlation matrix in the GEE model. Depression severity along with the level of sexual satisfaction versus infertility status was selected as dependent and independent variables, respectively. Confounding variables such as having a personal home, history of underlying illness and family marriage were selected for the multivariate model. Finally, chi-square test and fisher 's exact test was used to investigate the relationship between type of infertility, the type and cost of infertility treatment with both severity of depression and sexual dissatisfaction. SPSS software version 21 was used for data analysis at the significance level of 0.05 .

\section{ETHICAL CONSIDERATION}

The study was approved by the Ethics Committee of Lorestan University of Medical Sciences with a code number of lums.REC.1395.81. The participants were informed about the study goals. A consent form was completed by each one prior to enrollment in the study. In order to let participants become more comfortable, a female administrator interviewed them and they were promised the collected information would be kept confidential.

\section{Results}

We selected 180 infertile women and 540 fertile women from different cities of Lorestan, Iran for the purpose of our study. The mean age of cases and controls came up to $33.19 \pm 5.9$ and $33.11 \pm 4.9$ years, respectively (Table 1). Primary infertility was 
recognized as the most common reason for inability to reproduce (91.1\%). The most frequent methods of treatment were IVF (45.6\%) and drug therapy (43.8\%). A proportion of $70.6 \%$ of cases and $69.4 \%$ of controls were a housewife (Table 1 ). 
Table 1

Comparison of fertile and infertile people by demographic and contextual characteristics

\begin{tabular}{|c|c|c|c|c|c|c|}
\hline \multirow[t]{3}{*}{ Variables } & & \multicolumn{4}{|l|}{ Fertiliy } & \multirow[t]{3}{*}{ P-Value } \\
\hline & & \multicolumn{2}{|l|}{ Fertile } & \multicolumn{2}{|l|}{ Infertile } & \\
\hline & & Number & Percent & Number & Percent & \\
\hline \multirow[t]{2}{*}{ Age group } & $<35$ & 339 & $62.8 \%$ & 113 & $62.8 \%$ & \multirow[t]{2}{*}{$>0.999$} \\
\hline & $>=35$ & 201 & $37.2 \%$ & 67 & $37.2 \%$ & \\
\hline \multirow[t]{3}{*}{ Educational level } & IlliteraTE / Elementary Literate & 156 & $28.9 \%$ & 52 & $28.9 \%$ & \multirow[t]{3}{*}{$>0.999$} \\
\hline & High School Diploma & 204 & $37.8 \%$ & 68 & $37.8 \%$ & \\
\hline & University & 180 & $33.3 \%$ & 60 & $33.3 \%$ & \\
\hline \multirow[t]{2}{*}{ Marital duration category } & $<10$ years & 258 & $47.8 \%$ & 86 & $47.8 \%$ & \multirow[t]{2}{*}{$>0.999$} \\
\hline & $>=10$ years & 282 & $52.2 \%$ & 94 & $52.2 \%$ & \\
\hline \multirow[t]{2}{*}{ Occupational status } & Housewife & 375 & $69.4 \%$ & 127 & $70.6 \%$ & \multirow[t]{2}{*}{0.719} \\
\hline & Employed & 165 & $30.6 \%$ & 53 & $29.4 \%$ & \\
\hline \multirow[t]{3}{*}{ Spouses's educational level } & Illiterate / Elementary Literate & 205 & $38 \%$ & 73 & $40.6 \%$ & \multirow[t]{3}{*}{0.632} \\
\hline & High School Diploma & 152 & $28.1 \%$ & 49 & $27.2 \%$ & \\
\hline & University & 183 & $33.9 \%$ & 58 & $32.2 \%$ & \\
\hline \multirow[t]{4}{*}{ Spouses's occupational status } & Unemployed & 40 & $7.4 \%$ & 19 & $10.6 \%$ & \multirow[t]{4}{*}{0.463} \\
\hline & Employed & 126 & $23.3 \%$ & 38 & $21.1 \%$ & \\
\hline & Self-Employed & 296 & $54.8 \%$ & 99 & $55 \%$ & \\
\hline & Other & 78 & $14.4 \%$ & 24 & $13.3 \%$ & \\
\hline \multirow[t]{2}{*}{ Housing status } & Rented/Living in Parental Housing & 143 & $26.5 \%$ & 59 & $32.8 \%$ & \multirow[t]{2}{*}{0.079} \\
\hline & Owned & 397 & $73.5 \%$ & 12 & $67.2 \%$ & \\
\hline \multirow[t]{3}{*}{ Household income } & $<1000,000$ & 115 & $21.3 \%$ & 42 & $23.3 \%$ & \multirow[t]{3}{*}{0.787} \\
\hline & $1000,000-1999,000$ & 164 & $30.4 \%$ & 55 & $30.6 \%$ & \\
\hline & $>=2000,000$ & 261 & $48.3 \%$ & 83 & $46.1 \%$ & \\
\hline \multirow[t]{2}{*}{ Cousin marriage } & No & 352 & $65.2 \%$ & 106 & $58.9 \%$ & \multirow[t]{2}{*}{0.155} \\
\hline & Yes & 188 & $34.8 \%$ & 74 & $41.1 \%$ & \\
\hline \multirow[t]{2}{*}{ History of specific disease } & No & 484 & $89.6 \%$ & 144 & $80 \%$ & \multirow[t]{2}{*}{0.003} \\
\hline & yes & 56 & $10.4 \%$ & 36 & $20 \%$ & \\
\hline \multirow[t]{2}{*}{ Poison exposure } & No & 506 & $93.7 \%$ & 164 & $91.1 \%$ & \multirow[t]{2}{*}{0.273} \\
\hline & Yes & 34 & $6.3 \%$ & 16 & $8.9 \%$ & \\
\hline \multirow[t]{2}{*}{ Type of Infertility } & Primary & & & 164 & $(91.1)$ & \\
\hline & Secondary & & & 16 & (8.9) & \\
\hline
\end{tabular}

*These variables were taken into consideration in matching two groups

The GEE method with a logit link fuction was used. In each separate GEE, "Infertility status" was considered as the dependent variable and each single demographic predictor was used as an independent variable. 


\begin{tabular}{|llll|}
\hline Cost of Treating Infertility & $<$ US\$ 1500 & 35 & $(19.4)$ \\
\cline { 2 - 4 } & $\geq$ US\$ 1500 & 145 & $(80.6)$ \\
\hline Type of Infertility Treatment & Drug therapy & 79 & $(43.8)$ \\
\cline { 2 - 4 } & Surgery & 9 & $(5.0)$ \\
\hline & IVF & 82 & $(45.6)$ \\
\cline { 2 - 4 } & ICSI / IUI & 10 & $(5.6)$ \\
\hline *These variables were taken into consideration in matching two groups & & \\
\hline $\begin{array}{l}\text { The GEE method with a logit link fuction was used. In each separate GEE, “Infertility status" was considered as the dependent } \\
\text { variable and each single demographic predictor was used as an independent variable. }\end{array}$ \\
\hline
\end{tabular}

The marginal model with logit link function showed that there was a significant difference between the two groups of fertile and infertile in terms of distribution of history of underlying diseases $(P=0.003)$. Also, there was a significant difference between the two groups in terms of distribution of residential status and family marriage ( $P=0.07$ and $P=0.155$, respectively). Based on the aforementioned marginal model, there was no statistically significant difference between the two groups in terms of other underlying and demographic variables $(P>0.05)($ Table 1$)$.

Table 2 shows the relationship between severity of depression and sexual satisfaction with demographic and underlying variables in women. Confounding variables that correlate with both fertility status and severity of depression severity as well as level of sexual satisfaction can be assessed by Tables 1 and 2 . 
Table 2

The relationship between depression severity and sexual satisfaction with demographic and underlying variables in women

\begin{tabular}{|c|c|c|c|c|c|c|c|c|}
\hline \multirow[t]{3}{*}{ Variables } & & \multicolumn{3}{|c|}{ Beck depression category } & \multirow[t]{3}{*}{$\begin{array}{l}\mathrm{P} \\
\text { Value }\end{array}$} & \multicolumn{2}{|c|}{$\begin{array}{l}\text { Sexual satisfaction } \\
\text { category }\end{array}$} & \multirow[t]{3}{*}{$\begin{array}{l}\mathrm{P} \\
\text { value }\end{array}$} \\
\hline & & Borderline/Moderate & Severe & Extreme & & $\begin{array}{l}\text { Weak/ } \\
\text { Moderate }\end{array}$ & good & \\
\hline & & No(\%) & $\mathrm{No}(\%)$ & No(\%) & & No(\%) & $\mathrm{No}(\%)$ & \\
\hline \multirow[t]{2}{*}{ Age group } & $<35$ & $249(55.1)$ & $119(26.3)$ & $84(18.6)$ & \multirow[t]{2}{*}{0.147} & $12(2.7)$ & $440(97.3)$ & \multirow[t]{2}{*}{0.165} \\
\hline & $>=35$ & $139(51.9)$ & $64(23.9)$ & $65(24.3)$ & & $12(4.5)$ & 256(95.5) & \\
\hline \multirow[t]{3}{*}{$\begin{array}{l}\text { Educational } \\
\text { Level }\end{array}$} & $\begin{array}{l}\text { Illiteracy / } \\
\text { Elementary } \\
\text { Literacy }\end{array}$ & $91(43.8)$ & $55(26.4)$ & $62(29.8)$ & \multirow[t]{3}{*}{$<.001$} & $12(5.8)$ & 196(94.2) & \multirow[t]{3}{*}{0.026} \\
\hline & $\begin{array}{l}\text { High School / } \\
\text { Diploma }\end{array}$ & 151(55.5) & $74(27.2)$ & 47(17.3) & & $10(3.7)$ & 262(96.3) & \\
\hline & University & $146(60.8)$ & $54(22.5)$ & $40(16.7)$ & & $2(0.8)$ & 238(99.2) & \\
\hline \multirow{2}{*}{$\begin{array}{l}\text { Marital } \\
\text { Duration } \\
\text { Category }\end{array}$} & $<10$ years & 197(57.3) & $96(27.9)$ & $51(14.8)$ & \multirow[t]{2}{*}{0.001} & $7(2)$ & $337(98)$ & \multirow[t]{2}{*}{0.058} \\
\hline & $>=10$ years & 191(50.8) & $87(23.1)$ & $98(26.1)$ & & $17(4.5)$ & $359(95.5)$ & \\
\hline \multirow{2}{*}{$\begin{array}{l}\text { Occupational } \\
\text { Status }\end{array}$} & Housewife & $255(50.8)$ & $132(26.3)$ & $115(22.9)$ & \multirow[t]{2}{*}{0.002} & $22(4.4)$ & $480(95.6)$ & \multirow[t]{2}{*}{0.030} \\
\hline & Employed & 133(61) & $51(23.4)$ & $34(15.6)$ & & $2(0.9)$ & 216(99.1) & \\
\hline \multirow[t]{3}{*}{$\begin{array}{l}\text { Spouses' } \\
\text { Educational } \\
\text { Level }\end{array}$} & $\begin{array}{l}\text { Illiteracy / } \\
\text { Elementary } \\
\text { Literacy }\end{array}$ & $134(48.2)$ & $70(25.2)$ & $74(26.6)$ & \multirow[t]{3}{*}{0.001} & $12(4.3)$ & 266(95.7) & \multirow[t]{3}{*}{0.054} \\
\hline & $\begin{array}{l}\text { High School / } \\
\text { Diploma }\end{array}$ & $110(54.7)$ & $59(29.4)$ & $32(15.9)$ & & $10(5)$ & 191(95) & \\
\hline & University & 144(59.8) & $54(22.4)$ & $43(17.8)$ & & $2(0.8)$ & $239(99.2)$ & \\
\hline \multirow{4}{*}{$\begin{array}{l}\text { Spouses' } \\
\text { Occupational } \\
\text { Status }\end{array}$} & Unemployed & $19(32.2)$ & $22(37.3)$ & $18(30.5)$ & \multirow[t]{4}{*}{0.001} & $5(8.5)$ & $54(91.5)$ & \multirow[t]{4}{*}{0.113} \\
\hline & Employed & 101(61.6) & $34(20.7)$ & $29(17.7)$ & & $3(1.8)$ & $161(98.2)$ & \\
\hline & $\begin{array}{l}\text { Self } \\
\text { Employed }\end{array}$ & $214(54.2)$ & $105(26.6)$ & $76(19.2)$ & & 13(3.3) & $382(96.7)$ & \\
\hline & Others & $54(52.9)$ & $22(21.6)$ & $26(25.5)$ & & $3(2.9)$ & $99(97.1)$ & \\
\hline \multirow[t]{2}{*}{$\begin{array}{l}\text { Housing } \\
\text { Status }\end{array}$} & $\begin{array}{l}\text { Rented/Living } \\
\text { in Parental } \\
\text { Housing }\end{array}$ & $102(50.5)$ & $53(26.2)$ & $47(23.3)$ & \multirow[t]{2}{*}{0.323} & $8(4)$ & 194(96) & \multirow[t]{2}{*}{0.575} \\
\hline & owned & $286(55.2)$ & $130(25.1)$ & 102(19.7) & & 16(3.1) & $502(96.9)$ & \\
\hline \multirow{3}{*}{$\begin{array}{l}\text { Household } \\
\text { Income }\end{array}$} & $<1000,000$ & 61(38.9) & $49(31.2)$ & 47(29.9) & \multirow{3}{*}{$<.001$} & $11(7)$ & 146(93) & \multirow[t]{3}{*}{0.011} \\
\hline & $\begin{array}{l}1000,000- \\
1999,000\end{array}$ & 108(49.3) & $69(31.5)$ & 42(19.2) & & $5(2.3)$ & 214(97.7) & \\
\hline & $>=2000,000$ & 219(63.7) & 65(18.9) & $60(17.4)$ & & $8(2.3)$ & $336(97.7)$ & \\
\hline \multirow{2}{*}{$\begin{array}{l}\text { History of } \\
\text { Specific } \\
\text { Disease }\end{array}$} & No & $359(57.2)$ & $154(24.5)$ & 115(18.3) & \multirow{2}{*}{$\begin{array}{l}< \\
0.001\end{array}$} & $16(2.5)$ & $612(97.5)$ & 0.003 \\
\hline & Yes & 29(31.5) & $29(31.5)$ & $34(37)$ & & $8(8.7)$ & $84(91.3)$ & \\
\hline Cousin & No & $258(56.3)$ & $112(24.5)$ & $88(19.2)$ & 0.082 & $10(2.2)$ & $448(97.8)$ & 0.030 \\
\hline
\end{tabular}




\begin{tabular}{|c|c|c|c|c|c|c|c|c|}
\hline \multirow{3}{*}{$\begin{array}{l}\text { Poison } \\
\text { Exposure }\end{array}$} & Yes & $130(49.6)$ & 71(27.1) & $61(23.3)$ & & 14(5.3) & $248(94.7)$ & \\
\hline & No & $374(55.8)$ & $169(25.2)$ & 127(19) & \multirow{2}{*}{$<.001$} & $20(3)$ & $650(97)$ & \multirow[t]{2}{*}{0.039} \\
\hline & Yes & $14(28)$ & 14(28) & 22(44) & & $4(8)$ & $46(92)$ & \\
\hline
\end{tabular}

The marginal model showed that by modifying the effects of confounding variables (including marital duration, history of underlying diseases, and family marriage), infertility increased the odds of relatively high levels of depression by approximately 2.305 times $(\mathrm{OR}=2.305,95 \% \mathrm{Cl}$ for $\mathrm{OR}=14.75-32.021, \mathrm{P}<0.001)$. The marginal model showed that by moderating the effects of confounding variables (including marital duration, underlying disease history, and family marriage), infertility increased the chance of relatively low level of marital satisfaction by 15.560 times $(\mathrm{OR}=15.560,95 \% \mathrm{Cl}$ for $\mathrm{OR}=5.089-47.571, \mathrm{P}<0.001)$.

Chi-square test (Monte Carlo simulation) showed no significant relationship between severity of depression and infertility in infertile women $(p=0.856)$ (Table 3 ) and Fisher's exact test showed no significant relationship between infertility type and sexual satisfaction level $(P=0.701)$ (Table 4). The results of Chi-square test (Monte Carlo simulation) showed that there is a significant relationship between infertility treatment and severity of depression among infertile women $(P=0.001)$. Most cases of severe depression belonged to the IVF treatment group while the least cases of them appeared in IUI / ICSI group. Chi-square test (Monte Carlo simulation) showed no significant relationship between infertility treatment and sexual satisfaction level in infertile women $(p=0.242)$. However, most women who were mild to moderately satisfied with their sexual relationship were seen in surgical treatment and then in IVF units, respectively (22.2\% and $14.6 \%$, correspondingly)(Table 5).

Table 3

Modeling the effect of female infertility on the severity of depression and level of sexual satisfaction

\begin{tabular}{|c|c|c|c|c|c|c|}
\hline \multicolumn{7}{|c|}{ Modeling the effect of female infertility on the severity of depression } \\
\hline Model & $\begin{array}{l}\text { Fertility } \\
\text { Status }\end{array}$ & $\begin{array}{l}\text { Regression } \\
\text { Coefficient }\end{array}$ & The Standard Error & Odds ratio & $\begin{array}{l}95 \% \text { confidence } \\
\text { for odds ratio }\end{array}$ & P Value \\
\hline \multirow{2}{*}{$\begin{array}{l}\text { Without } \\
\text { Adjustment }\end{array}$} & Infertile & 3.052 & 0.205 & 21.164 & $14.172-31.603$ & $<0.001$ \\
\hline & Fertile & Base Category & & & & \\
\hline \multirow{2}{*}{$\begin{array}{l}\text { With } \\
\text { Adjustment }\end{array}$} & Infertile & 3.052 & 0.208 & 21.305 & $14.175-32.021$ & $<0.001$ \\
\hline & Fertile & Base Category & & & & \\
\hline
\end{tabular}

Modeling the Effect of Female Infertility on Lower Sexual Satisfaction

\begin{tabular}{llllllll} 
Model & Fertility Status & $\begin{array}{l}\text { Regression } \\
\text { Coefficient }\end{array}$ & Standard Error & Odds Ratio & $\begin{array}{l}95 \% \text { confidence } \\
\text { interval for Odds Ratio }\end{array}$ & $\begin{array}{c}P \\
\text { Value }\end{array}$ \\
$\begin{array}{l}\text { Without } \\
\text { Adjustment }\end{array}$ & Infertile & 2.818 & 0.563 & 16.750 & $5.557-50.492$ & $<$ \\
\hline
\end{tabular}

\begin{tabular}{|c|c|c|c|c|c|c|}
\hline & Fertile & Base Category & & & & \\
\hline $\begin{array}{l}\text { With } \\
\text { Adjustment }\end{array}$ & Infertile & 2.745 & 0.570 & 15.560 & $5.089-47.571$ & $\begin{array}{l}< \\
0.001\end{array}$ \\
\hline
\end{tabular}

Fertile Base Category

In this model, the effect of marital duration, history of underlying illness and family marriage has been adjusted. 
Table 4

Relationship between severity of depression and sexual satisfaction with infertility in infertile women

\begin{tabular}{|c|c|c|c|c|c|c|c|}
\hline \multirow[t]{3}{*}{ Type of Infertility } & \multicolumn{3}{|l|}{ Severity of Depression } & \multirow[t]{3}{*}{ P Value } & \multicolumn{2}{|c|}{ Level of Sexual Satisfaction } & \multirow{3}{*}{$\begin{array}{l}\text { P Value } \\
0.701\end{array}$} \\
\hline & Moderate/Borderline & Severe & Very Severe & & Moderate/Poor & Good & \\
\hline & $\mathrm{No}(\%)$ & $\mathrm{No}(\%)$ & $\mathrm{No}(\%)$ & & $\mathrm{No}(\%)$ & $\mathrm{No}(\%)$ & \\
\hline Primary Infertility & 15(9.1) & $47(28.7)$ & $102(62.2)$ & 0.856 & 19(11.6) & $145(88.4)$ & \\
\hline Secondary Infertility & $2(12.5)$ & $5(31.3)$ & $9(56.3)$ & & $1(6.3)$ & 15(93.8) & \\
\hline
\end{tabular}

Table 5

The relationship between depression severity and sexual satisfaction levels with infertility treatment in infertile women

\begin{tabular}{|c|c|c|c|c|c|c|c|}
\hline \multirow{3}{*}{$\begin{array}{l}\text { Method of Infertility } \\
\text { Treatment }\end{array}$} & \multicolumn{3}{|l|}{ Severity of Depression } & \multirow{3}{*}{$\begin{array}{l}\mathrm{P} \\
\text { Value }\end{array}$} & \multicolumn{2}{|l|}{$\begin{array}{l}\text { Levels of Sexual } \\
\text { Satisfaction }\end{array}$} & \multirow{3}{*}{$\begin{array}{l}\mathrm{P} \\
\text { Value } \\
0.242\end{array}$} \\
\hline & Borderline/Moderate & Severe & $\begin{array}{l}\text { Very } \\
\text { Severe }\end{array}$ & & Moderate/Poor & Good & \\
\hline & $\mathrm{No}(\%)$ & $\mathrm{No}(\%)$ & $\mathrm{No}(\%)$ & & No(\%) & $\mathrm{No}(\%)$ & \\
\hline Drug therapy & $12(15.2)$ & $28(35.4)$ & $39(49.4)$ & \multirow[t]{4}{*}{0.001} & $5(6.3)$ & 74(93.7) & \\
\hline Surgery & $2(22.2)$ & $2(22.2)$ & $5(55.6)$ & & $2(22.2)$ & $7(77.8)$ & \\
\hline IVF & $3(3.7)$ & 15(18.3) & $64(78) \star$ & & $12(14.6)$ & $70(85.4)$ & \\
\hline IUI/ICSI & $0(0)$ & $7(70)$ & $3(30)$ & & $1(10)$ & $9(90)$ & \\
\hline
\end{tabular}

Chi-square test (Monte Carlo simulation) showed no significant relationship between the cost of infertility treatment and the severity of depression $(P=0.098)$. As such, the prevalance of sever depression was higher among women who spent more than 5 million toomans for infertilty treatment compared to those who paid less than that (65.5\% Vs. $45.7 \%)$. Fisher exact test showedthere was no significant relationship between sexual satisfaction and costs of infertility treatment $(P=0.373)$. However, it seems that women who spent more than five million toomans for the purpose ot infertility treatment were less satistied than those who paid less $(12.4 \%$ Vs. $5.7 \%)$ (Table 6).

Table 6

Evaluation of the relationship between the cost of infertility treatment with the severity of depression and levels of sexual satisfaction

\begin{tabular}{|c|c|c|c|c|c|c|c|}
\hline \multirow{3}{*}{$\begin{array}{l}\text { The cost of infertility } \\
\text { treatment }\end{array}$} & \multicolumn{3}{|c|}{ Severity of depression } & \multirow{3}{*}{$\begin{array}{l}\mathrm{P} \\
\text { Value }\end{array}$} & \multicolumn{2}{|c|}{ Level of sexual satisfaction } & \multirow{3}{*}{$\begin{array}{l}\mathrm{P} \\
\text { Value }\end{array}$} \\
\hline & $\begin{array}{l}\text { Borderline / } \\
\text { Poor }\end{array}$ & Severe & $\begin{array}{l}\text { Very } \\
\text { Severe }\end{array}$ & & $\begin{array}{l}\text { Poor / } \\
\text { Moderate }\end{array}$ & Good & \\
\hline & $\mathrm{No}(\%)$ & $\mathrm{No}(\%)$ & $\mathrm{No}(\%)$ & & $\mathrm{No}(\%)$ & $\mathrm{No}(\%)$ & \\
\hline 5 Million> & $5(14.3)$ & $14(40)$ & $16(45.7)$ & \multirow[t]{3}{*}{0.098} & $2(5.7)$ & $33(94.3)$ & \multirow[t]{3}{*}{0.373} \\
\hline$<=5$ Million & $12(8.3)$ & $38(26.2)$ & $95(65.5)$ & & 18(12.4) & $127(87.6)$ & \\
\hline Total & $17(9.4)$ & $52(28.9)$ & $111(61.7)$ & & $20(11.1)$ & $160(88.9)$ & \\
\hline
\end{tabular}

\section{Discussion}

According to the result, infertile women are 21 times more likely to develop depression compared to the fertile ones. After adjusting for confounding variables such as marital duration, history of underlying illnesses, and family marriage, the chances of contracting depression still remains higher in infertile than fertile women by number of times. Since an infertile person is not able to go through the process of reproduction, she turns this failure into a social psychological crisis. A previous study in Iran measured psychological symptoms among infertile women using a similar tool to the one was used in the present study and found infertility has been a source of anxiety and depression among Iranian infertile women(11). 
Cultural and social factors may play a critical role in the psychological status of Iranian infertile women as well $(8,11,30)$. Infertile women experience various forms of ignorance in the family and society, thus; let them avoid the community which does not appropriate for their social health while may even exacerbate their psychological symptoms $(8,31,32)$. Based on a qualitative study that examined the experiences of infertile Nigerian women, most women expressed anxiety and depression as a result of their inability to get pregnant. They also suffered from social self-isolation and marital problems(33). Likewise, a study measured mood distress in infertile couples again which used similar tools used in our study. That showed about $10 \%$ of the sample experience clinical symptoms of anxiety and depression(14).The results of our study are consistent with previous studies which shows anxiety and depression are common manifestations among infertile women.

According to the results of our study, the chance of insufficient sexual satisfaction is higher by 15 times among infertile women compared to fertile ones. Based on a few Iranian studies, the infertile couples' welfare and relationships are more likely to be affected by infertility in countries where a daughter has been trained and expected to be a mother later on $(11,30,34-38)$. Various studies have already measured the levels of sexual satisfaction among infertile women using different tools. For example a previous study conducted in Iran, measured the levels of sexual satisfaction using the Female Sexual Function Index Questionnaire which showed the levels of satisfaction is significantly lower in infertile group compared to the opposite cluster(37). These findings show that the results of sexual satisfaction assessment in Iranian infertile women are similar by different questionnaires. Likewise, a meta-analysis without language restriction on 11 comparative studies showed that infertility was associated with an increased sexual dysfunction(39).

According to the results of previous studies in Iran the prevalence of sexual dissatisfaction was significantly higher in infertile women compared to their husbands, which indicates infertile women were more affected by psychological complications of infertility than their spouses(40). In addition, Men and women may differ in their perceptions of sexual satisfaction. For example, a study of 113 infertile couples who attended an infertility clinic showed a higher proportion of women believe their partner do not understand how infertility issues have impacted their marital life. This can be an origin of concern about longevity of their relationships. In contrast, men reported having significant lower quality of sex compared to the women(41).

Our study demonstrated the severity of depression in infertile women who received IVF treatment increased over time. A systematic review reported multiple failed IVF treatment attempts may increase the likelihood of developing unfavorable mood conditions, especially depression. For instance, Infertility treatment affects changes in perception, marital relationship, and personality of an infertile woman(42).

Previous studies have also shown that treatment of infertility are sometimes predictive of stressful conditions related to infertility rather than getting them fertile $(43,44)$. It may be thought that seeking fertility may take the form of obsessive-compulsive behavior that may affect couples' self-esteem and identity. Couples may feel they are responsible for the outcome of the pregnancy, which raises concerns. This causes couples to neglect other aspects of life, making them susceptible to depressive traits such as declined social and physical activity as well as the interest in daily life(45).There is a mutual relationship between depression and infertility treatment. During a study conducted in North Carolina, U.S. infertile women who already started receiving treatment were given the NIH PROMIS screening tool questionnaire which screens people for mental disorders. Infertile women who suffered from depression were less likely to follow oral or IVF treatments than infertile women who were not depressed(46).

Our study demonstrated low sexual satisfaction is commonly seen in women undergoing infertility treatment through surgery and IVF. Couples' focus on pregnancy may diminish their interest in sexual activity. In addition, sexual problems in the treatment of infertility may be attributed to hormonal changes produced as a result of medical treatments such as surgery or IVF(47). A previous study in Iran showed that poor general health, stress, and marital dissatisfaction were associated with IVF treatment in infertile women(48).In a study of three target groups, including successful IVF treatment group, unsuccessful IVF treatment group with a step kid, and unsuccessful IVF treatment group with no step kin at all, there were no significant differences between them in terms of sexual satisfaction. They did not have sexual satisfaction and indicated(49). This may indicate the negative impact of IVF treatment on having sexual satisfaction. Studies show that people who find fertility through medical treatment experience symptoms of anxiety, stress, depression, and sexual concerns related to infertility. When infertile group got pregnant by means of 
reproductive medical assistance, if the women of previously infertile group were exposed to stressors, they showed a greater decline in sexual satisfaction(50).

In addition our study demonstrated, relatively high level of depression and low level of sexual satisfaction are seen among infertile women, while the cost of treating them has been at least 5 million Tomans. In a study of 85 Iranian infertile women referred to a public clinic in order to assess sexual satisfaction, the cost of treatment was significantly associated with sexual function. Women who are positive for depression screening are more prone to long-term infertility. In contrast, infertile women who are not depressed they are less likely to start and continue infertility treatment(51)

Our study has many strong points and we are absolutely confident in the validity of the results. The fact that it was a case-control study within a cohort of Lorestan, Iran enabled us to minimize the risk of selection bias. Likewise, the confounding factors were well identified. Data of confounding variables was available and the effects of them were controlled over the multivariate marginal model. Nonetheless, our study was not without limitations. Due to the fact that marital issues are considered extremely a private topic and that there are cultural and religious restrictions at this point in Iran, people may not be able to open up and tell the truth. Therefore, the inability of most individuals to express themselves explicitly was beyond the reach of the researchers, so the present study only includes psychological assessment of women. For future studies, it is suggested that both data of woman and her spouse to be examined simultaneously. In addition, considering that this is a non-longitudinal case-control study; we have had difficulty controlling it for some confounding variables. Therefore, prospective longitudinal studies are recommended for future studies on this link.

\section{Conclusion}

The present study showed the severity of depression and sexual dissatisfaction in infertile group was more than fertile group. There was also a significant relationship between the type of infertility treatment and the severity of depression in infertile women. Most cases of very severe depression were seen in IVF treatment, which causes this defective cycle and exacerbates the depression due to infertility and sexual satisfaction. This may reduce treatment failure and decrease the chance of fertility. Therefore, screening women for depression by health personnel is important because follow-up and subsequent interventions may improve fertility compliance, quality of life, and overall sexual pleasure. It is suggested that psychiatric counseling services be available in all infertility treatment centers to address the psychological and behavioral needs and problems of infertile patients from the time of diagnosis to the end of the treatment process.

\section{Abbreviations}

GEE: Generalized Estimating Equations

WHO: World Health Organization

\section{Declarations}

\section{Ethics approval and consent to participate}

The study was approved by the Ethics Committee of the Lorestan University of Medical Sciences with the code number of lums.REC.1395.81. The participants were informed about the study goals. A consent form was completed by each one before enrolment in the study. In order to let participants more comfortable a female administrator interviewed them and the collected information was kept confidential.

\section{Consent for publication:}

Not applicable 


\section{Availability of data and material:}

The datasets used and/or analyzed during the current study are provided by the corresponding author on a reasonable request.

\section{Competing interests:}

All authors have read and approved the content of the article. The authors declared no potential conflicts of interest with respect to the research, authorship, and/or publication of this article.

\section{Funding:}

This study was funded by Lorestan University of Medical Sciences as a research project under registration number 1285.

\section{Authors' contributions:}

FE and $\mathrm{K} \mathrm{B}$ have made substantial contributions to the conception and design of the manuscript. $\mathrm{M} \mathrm{A}$ and $\mathrm{K} B$ participated in the study design and data acquisition. AA and F B were involved in drafting and revising the manuscript,

\section{Acknowledgements:}

The researchers would like to express their gratitude to the participants and the staff of the health centers of Lorestan, Iran.

\section{References}

1. Sharma S, RoyChoudhury S, Bathwal S, Bhattacharya R, Kalapahar S, Chattopadhyay R, et al. Pregnancy and Live Birth Rates Are Comparable in Young Infertile Women Presenting with Severe Endometriosis and Tubal Infertility. Reproductive sciences (Thousand Oaks, Calif). 2020.

2. Vander Borght M, Wyns C. Fertility and infertility: Definition and epidemiology. Clinical biochemistry. 2018;62:2-10.

3. Day WH. MMWR Morbidity and mortality weekly report. 2019;68(29).

4. Kazemijaliseh H, Ramezani Tehrani F, Behboudi-Gandevani S, Hosseinpanah F, Khalili D, Azizi F. The Prevalence and Causes of Primary Infertility in Iran: A Population-Based Study. Global journal of health science. 2015;7(6):226-32.

5. Rooney KL, Domar AD. The relationship between stress and infertility. Dialogues in clinical neuroscience. 2018;20(1):41-7.

6. Inhorn MC, Patrizio P. Infertility around the globe: new thinking on gender, reproductive technologies and global movements in the 21st century. Human reproduction update. 2015;21(4):411-26.

7. Carvalho N, Salehi AS, Goldie SJ. National and sub-national analysis of the health benefits and cost-effectiveness of strategies to reduce maternal mortality in Afghanistan. Health policy and planning. 2013;28(1):62-74.

8. Bakhtiyar K, Beiranvand R, Ardalan A, Changaee F, Almasian M, Badrizadeh A, et al. An investigation of the effects of infertility on Women's quality of life: a case-control study. BMC women's health. 2019;19(1):114.

9. Omani-Samani R, Maroufizadeh S, Almasi-Hashiani A, Sepidarkish M, Amini P. The WHO-5 Well-Being Index: A Validation Study in People with Infertility. Iranian journal of public health. 2019;48(11):2058-64.

10. Amiri M, Khosravi A, Chaman R, Sadeghi Z, Raei M, Jahanitiji M, et al. Social Consequences of Infertility on Families in Iran. Global journal of health science. 2015;8(5):89-95.

11. Shahraki Z, Tanha FD, Ghajarzadeh M. Depression, sexual dysfunction and sexual quality of life in women with infertility. BMC women's health. 2018;18(1):92.

12. Gdanska P, Drozdowicz-Jastrzebska E, Grzechocinska B, Radziwon-Zaleska M, Wegrzyn P, Wielgos M. Anxiety and depression in women undergoing infertility treatment. Ginekologia polska. 2017;88(2):109-12. 
13. Fu B, Qin N, Cheng L, Tang G, Cao Y, Yan C, et al. Development and validation of an Infertility Stigma Scale for Chinese women. Journal of psychosomatic research. 2015;79(1):69-75.

14. Pozza A, Dettore D, Coccia ME. Depression and Anxiety in Pathways of Medically Assisted Reproduction: The Role of Infertility Stress Dimensions. Clinical practice and epidemiology in mental health : CP \& EMH. 2019;15:101-9.

15. Brotto L, Atallah S, Johnson-Agbakwu C, Rosenbaum T, Abdo C, Byers ES, et al. Psychological and interpersonal dimensions of sexual function and dysfunction. The journal of sexual medicine. 2016;13(4):538-71.

16. Güleç G, Hassa H, GÜNES E, YENILMEZ Ç. The effects of infertility on sexual functions and dyadic adjustment in couples that present for infertility treatment. Turkish journal of psychiatry. 2011;22(3).

17. Skałacka K, Gerymski R. Sexual activity and life satisfaction in older adults. Psychogeriatrics : the official journal of the Japanese Psychogeriatric Society. 2019;19(3):195-201.

18. Gewirtz-Meydan A, Finzi-Dottan R. Sexual satisfaction among couples: The role of attachment orientation and sexual motives. The Journal of Sex Research. 2018;55(2):178-90.

19. Schmiedeberg C, Schröder J. Does sexual satisfaction change with relationship duration? Archives of sexual behavior. 2016;45(1):99-107.

20. Carter J, Applegarth L, Josephs L, Grill E, Baser RE, Rosenwaks Z. A cross-sectional cohort study of infertile women awaiting oocyte donation: the emotional, sexual, and quality-of-life impact. Fertility and sterility. 2011;95(2):711-6. e1.

21. Ozturk S, Sut HK, Kucuk L. Examination of sexual functions and depressive symptoms among infertile and fertile women. Pakistan journal of medical sciences. 2019;35(5):1355.

22. Masoumi SZ, Khani S, Kazemi F, Kalhori F, Ebrahimi R, Roshanaei G. Effect of marital relationship enrichment program on marital satisfaction, marital intimacy, and sexual satisfaction of infertile couples. International journal of fertility \& sterility. 2017;11(3):197.

23. Masoumi SZ, Garousian M, Khani S, Oliaei SR, Shayan A. Comparison of quality of life, sexual satisfaction and marital satisfaction between fertile and infertile couples. International journal of fertility \& sterility. 2016;10(3):290.

24. Wang YP, Gorenstein C. Psychometric properties of the Beck Depression Inventory-ll: a comprehensive review. Revista brasileira de psiquiatria (Sao Paulo, Brazil : 1999). 2013;35(4):416-31.

25. MOUSAVI SA, Aghayan S, Razavianzadeh N, Nourouzi N, Khosravi A. Depression and General health status in type ii diabetic patients. 2008.

26. Bendal R, Afifi A. Comparison of stopping rules in forward regression. J Am Stat Assoc. 1977;72(357):46-53.

27. Mickey RM, Greenland S. The impact of confounder selection criteria on effect estimation. American journal of epidemiology. 1989;129(1):125-37.

28. Liang K-Y, Zeger SL. Longitudinal data analysis using generalized linear models. Biometrika. 1986;73(1):13-22.

29. Zhang Z. Model building strategy for logistic regression: purposeful selection. Annals of translational medicine. 2016;4(6).

30. SHAHRAKI Z, GHAJARZADEH M, GANJALI M. Depression, Anxiety, Quality of Life and Sexual Dysfunction in Zabol Women with Infertility. Mædica. 2019;14(2):131.

31. Naab F, Brown R, Heidrich S. Psychosocial health of infertile Ghanaian women and their infertility beliefs. Journal of Nursing Scholarship. 2013;45(2):132-40.

32. Joelsson LS, Tydén T, Wanggren K, Georgakis M, Stern J, Berglund A, et al. Anxiety and depression symptoms among subfertile women, women pregnant after infertility treatment, and naturally pregnant women. European psychiatry. 2017;45:2129.

33. Naab F, Lawali Y, Donkor ES. "My mother in-law forced my husband to divorce me": Experiences of women with infertility in Zamfara State of Nigeria. PloS one. 2019;14(12).

34. Maroufizadeh S, Hosseini M, Foroushani AR, Omani-Samani R, Amini P. The relationship between perceived stress and marital satisfaction in couples with infertility: actor-partner interdependence model. International journal of fertility \& sterility. 2019;13(1):66. 
35. Sahebalzamani M, Mostaedi Z, Farahani H, Sokhanvar M. Relationship between health literacy and sexual function and sexual satisfaction in infertile couples referred to the Royan Institute. International journal of fertility \& sterility.

2018;12(2):136.

36. Marvi N, Golmakani N, Miri HH, Esmaily H. The effect of sexual education based on sexual health model on the sexual function of women with infertility. Iranian journal of nursing and midwifery research. 2019;24(6):444.

37. Sahraeian M, Lotfi R, Qorbani M, Faramarzi M, Dinpajooh F, Ramezani Tehrani F. The Effect of Cognitive Behavioral Therapy on Sexual Function in Infertile Women: A Randomized Controlled Clinical Trial. Journal of sex \& marital therapy. 2019;45(7):574-84.

38. Omani-Samani R, Amini P, Navid B, Sepidarkish M, Maroufizadeh S, Almasi-Hashiani A. Prevalence of sexual dysfunction among infertile women in Iran: a systematic review and meta-analysis. International journal of fertility \& sterility. 2019;12(4):278.

39. de Mendonca CR, Arruda JT, Noll M, Paulo MdO, do Amaral WN. Sexual dysfunction in infertile women: A systematic review and meta-analysis. European Journal of Obstetrics \& Gynecology and Reproductive Biology. 2017;215:153-63.

40. Bahrami N, Sattar-Zadeh N, Ghajarzadeh M, Solaimani M-A, Sadeghi T, Kazemi H. The relationship between infertility and couples' sexual satisfaction. The Journal of Qazvin University of Medical Sciences. 2011;14(2).

41. Luk BH, Loke AY. Sexual satisfaction, intimacy and relationship of couples undergoing infertility treatment. Journal of reproductive and infant psychology. 2019;37(2):108-22.

42. Verhaak CM, Smeenk J, Evers A, Kremer JA, Kraaimaat F, Braat D. Women's emotional adjustment to IVF: a systematic review of 25 years of research. Human reproduction update. 2007;13(1):27-36.

43. Lakatos E, Szigeti JF, Ujma PP, Sexty R, Balog P. Anxiety and depression among infertile women: a cross-sectional survey from Hungary. BMC women's health. 2017;17(1):48.

44. Greil AL, McQuillan J, Lowry M, Shreffler KM. Infertility treatment and fertility-specific distress: A longitudinal analysis of a population-based sample of US women. Social Science \& Medicine. 2011;73(1):87-94.

45. Reis S, Xavier MR, Coelho R, Montenegro N. Psychological impact of single and multiple courses of assisted reproductive treatments in couples: a comparative study. European Journal of Obstetrics \& Gynecology and Reproductive Biology. 2013;171(1):61-6.

46. Crawford NM, Hoff HS, Mersereau JE. Infertile women who screen positive for depression are less likely to initiate fertility treatments. Human reproduction. 2017;32(3):582-7.

47. Samplaski MK, Nangia AK. Adverse effects of common medications on male fertility. Nature reviews urology. 2015;12(7):401.

48. Shakeri J, Hossieni M, Golshani S, Sadeghi K, Fizollahy V. Assessment of general health, stress coping and marital satisfaction in infertile women undergoing IVF treatment. Journal of Reproduction \& Infertility. 2006;7(3).

49. Leiblum SR, Aviv A, Hamer R. Life after infertility treatment: a long-term investigation of marital and sexual function. Human reproduction (Oxford, England). 1998;13(12):3569-74.

50. Repokari L, Punamäki R-L, Unkila-Kallio L, Vilska S, Poikkeus P, Sinkkonen J, et al. Infertility treatment and marital relationships: a 1-year prospective study among successfully treated ART couples and their controls. Human reproduction. 2007;22(5):1481-91.

51. Alirezaei S, Ozgoli G, Majd HA. Evaluation of factors associated with sexual function in infertile women. International journal of fertility \& sterility. 2018;12(2):125. 